\title{
PROTECTIVE ROLE OF SELENIUM AGAINST OVER-EXPRESSION OF CANCER-RELATED APOPTOTIC GENES INDUCED BY O-CRESOL IN RATS
}

\author{
Wagdy K. B. KHALIL and Hoda F. BOOLES \\ Cell Biology Department, National Research Centre, Dokki, Giza, Egypt \\ Received in September 2010 \\ Last CrossChecked in May 2011 \\ Accepted in March 2011
}

\begin{abstract}
Cresols are monomethyl derivatives of phenol frequently used as solvents and intermediates in the production of disinfectants, fragrances, pesticides, dyes, and explosives, which is probably why they are widely distributed in the environment. General population may be exposed to cresols mainly through inhalation of contaminated air. In this study we evaluated the toxicological effects of $o$-cresol on differential gene expression profile of rat liver and prostate. Experiments were conducted on 80 male rats, 60 of which were exposed to $o$-cresol $\left(1.5 \mathrm{~g} \mathrm{~kg}^{-1}, 5 \mathrm{~g} \mathrm{~kg}^{-1}\right.$, or $\left.15 \mathrm{~g} \mathrm{~kg}^{-1}\right)$ through feed for 8 weeks. Three groups of rats were supplemented with $0.1 \mathrm{mg} \mathrm{kg}^{-1}$ selenium (Se, in the form of, sodium selenite) in addition to $o$-cresol to evaluate its effectiveness against $o$-cresol toxicity. Control group received neither o-cresol nor Se, while one group received Se alone. Survival was similar between the exposed and control animals. Rats exposed to $15 \mathrm{~g} \mathrm{~kg}^{-1}$ of $o$-cresol showed a $16 \%$ loss in body weight by the end of the study, which may have been related to $o$-cresol making feed unpalatable at this concentration. Liver and prostate tissue samples were collected at the end of the treatment. mRNA analysis revealed that apoptotic genes (CYP3A, COX-2, PPAR $\gamma, \mathrm{BAX}, \mathrm{BCL} 2 \mathrm{AKT}-1$, and PKC $\alpha$ ) related to cancer were up-regulated in liver and prostate tissues isolated from groups exposed to $5 \mathrm{~g} \mathrm{~kg}^{-1}$ and $15 \mathrm{~g} \mathrm{~kg}^{-1} O$-cresol in comparison to control. Changes in gene expression profile were prevented when rats were supplemented with Se. The exact mechanisms underlying its protective effect remain to be clarified by future studies.
\end{abstract}

KEY WORDS: apoptotic genes, phenol derivatives, RT-PCR, trace element

Cresols are monomethyl derivatives of phenol that come in three isomers: ortho, meta, and para. In nature, cresols occur in some plant oils and are by-products of burning natural materials such as cigarettes, petroleum fuel, wood and coal (1). Commercially, cresols are either synthesised or distilled from petroleum or coal tar (2). They are used in a wide variety of products such as disinfectants, preservatives, dyes, fragrances, herbicides, insecticides, explosives, resin, rubber, polymers, elastomers, and food.

High production and distribution of cresols in the environment increase the risk of widespread exposure for humans. They have been found in food and drink
$(3,4)$, air, sediment, soil, and water (5-9). According to the US EPA, air cresol levels are about $32 \mathrm{ng} \mathrm{m}^{-3}$, rising to $1.5 \mu \mathrm{g} \mathrm{m}^{-3}$ for $o$-cresol in the vicinity of intense traffic and gas stations. In soil and groundwater these levels can be as high as $55 \mathrm{mg} \mathrm{kg}^{-1}$ and $16 \mathrm{mg}$ $\mathrm{L}^{-1}$, respectively (10).

Several regions in Egypt such as El-Mahalla ElKubra and Kafr El-Dawar cities have seen an industrial boom over the last decade (11). El-Mahalla El-Kubra is famous for textile dyeing and printing, but is also known for a water pollution problem with cresols and other contaminants, which threaten to enter the food chain and affect a larger fish population. 
Routes of cresol exposure (including metabolites and phenolic compounds such as toluene) for humans include inhalation, skin, or mouth (12-14). Cresols can irritate the respiratory tract (1) and affect the skin of rabbits (15) and humans exposed to cresolcontaining products $(1,16)$.

The carcinogenicity of cresols has yet to be determined. Boutwell and Bosch (17) observed increased incidence of skin papillomas in mice. Similarly, Yanysheva et al. (18) observed increased incidence of forestomach papillomas and carcinomas in mice. In contrast, Sanders et al. (19) found no clear evidence of cresol carcinogenicity in male rats and female mice.

Long and intense exposure to $o$-cresol may alter gene expression either directly or indirectly and lead to cancer. Only a few studies have investigated the genotoxicity of cresol, and none has investigated its effects on the expression of apoptotic genes associated with cancer development. Our study was therefore the first to investigate how exposure to $o$-cresol affected the expression of CYP3A, COX-2, PPAR $\gamma, \mathrm{BAX}$, BCL2, AKT-1, and $\mathrm{PKC} \alpha$, using reverse transcription polymerase chain reaction (RT-PCR). These have been established as reliable markers of carcinogenicity (20-24). In addition, we evaluated the protective effect of selenium against $o$-cresol-induced genetic alterations, whose antioxidative role has been well documented (25-33).

\section{MATERIALS AND METHODS}

\section{Chemicals}

Reagents and solvents used in this study were of the highest purity. $o$-cresol was purchased from SigmaAldrich (St. Louis, USA). Selenium was purchased from Merck-Schuchardt Chemical Co. (Darmstadt, Germany). Reagents for RT-PCR were purchased from Invitrogen (Paisley, UK) and Fermentas (LeonRot, Germany).

\section{Experimental Animals}

Eighty adult male albino rats weighing $120 \mathrm{~g}$ to $140 \mathrm{~g}$ were obtained from the Animal House Colony, National Research Centre, Giza, Egypt. The animals were kept individually in wire-bottom cages at room temperature $(25 \pm 2)^{\circ} \mathrm{C}$ under the 12-hour dark-light cycle. They were receiving standard laboratory diet and water ad libitum. The animals were allowed to adjust to new conditions for one week before the experiment started. All received care in compliance with the guidelines of the Ethics Committee of Medical Research, National Research Centre, Giza, Egypt.

\section{Experimental design}

After one-week adjustment to new conditions, the animals were divided in eight groups with ten rats in each, as follows: group 1 - untreated control ; groups 2,3 , and 4 - animals receiving basic diet (34) with 1.5 $\mathrm{g} \mathrm{kg}^{-1}, 5 \mathrm{~g} \mathrm{~kg}^{-1}$, or $15 \mathrm{~g} \mathrm{~kg}^{-1}$ of $o$-cresol, respectively; group 5 - animals receiving basic diet without $o$-cresol but supplemented intragastrically with $0.1 \mathrm{mg} \mathrm{kg}^{-1} \mathrm{Se}$ as sodium selenite; and groups 6 to 8 - animals receiving the same as groups 2,3 , and 4 plus $0.1 \mathrm{mg} \mathrm{kg}^{-1} \mathrm{Se}$. The experiment lasted eight weeks. The highest exposure concentrations of $o$-cresol were based on observations of minimal toxicity at these levels in previous cresol studies (35).

During the experiment, the animals were checked for morbidity and mortality twice a day. Body weights were recorded at baseline, every week, and at the end of the experiment, when the animals were euthanised and liver samples dissected and thoroughly washed with isotonic saline. Prostate tissues (seminal vesicles, prostate lobes, and bladder) were also removed and placed in a Petri dish containing PBS buffer $\left(137 \mathrm{mmol} \mathrm{L}^{-1} \mathrm{NaCl}, 3 \mathrm{mmol} \mathrm{L}^{-1} \mathrm{KCl}, 4 \mathrm{mmol} \mathrm{L}^{-1}\right.$ $\mathrm{Na}_{2} \mathrm{HPO}_{4}$, and $1.5 \mathrm{mmol} \mathrm{L}^{-1} \mathrm{KH}_{2} \mathrm{PO}_{4}, \mathrm{pH}$ 7.4) to prevent desiccation. The bladder was emptied, and the tissues gently blotted to remove excess PBS. Tissues were then snap-frozen in liquid nitrogen and stored at $-80^{\circ} \mathrm{C}$ until analysis.

\section{Semi-quantitative RT-PCR}

First-strand cDNA synthesis from extracted rat $R N A$

Total RNA (Poly(A) ${ }^{+}$RNA) was extracted from $50 \mathrm{mg}$ of liver and prostate tissues using the standard TRIzol extraction method (Invitrogen, Paisley, UK) and recovered in $100 \mu \mathrm{L}$ diethylpyrocarbonate (DEPC)-treated water by passing the solution a few times through a pipette tip.

Total RNA was treated with one unit of RQ1 RNAse-free DNAse (Invitrogen, Karlsruhe, Germany) to digest DNA residues, re-suspended in DEPC-treated water, and quantified photospectrometrically at $260 \mathrm{~nm}$. Total RNA was assessed for purity from the ratio between quantifications at $260 \mathrm{~nm}$ and $280 \mathrm{~nm}$, 
and was between 1.8 and 2.1. Integrity was verified with the ethidium bromide-stain analysis of $28 \mathrm{~S}$ and $18 \mathrm{~S}$ bands using formaldehyde-containing agarose gel electrophoresis. Aliquots were either used immediately for reverse transcription (RT) or stored at $-80^{\circ} \mathrm{C}$.

To synthesise first-strand cDNA, $5 \mu \mathrm{g}$ of complete Poly $(\mathrm{A})^{+}$RNA was reverse transcribed into cDNA in a total volume of $20 \mu \mathrm{L}$ using $1 \mu \mathrm{L}$ oligo [poly(deoxythymidine) $)_{18}$ ] primer(36). The composition of the reaction mixture was $50 \mathrm{mmol} \mathrm{L}^{-1} \mathrm{MgCl}_{2}, 10 \mathrm{x}$ RT buffer $\left(50 \mathrm{mmol} \mathrm{L}^{-1} \mathrm{KCl} ; 10 \mathrm{mmol} \mathrm{L}^{-1}\right.$ Tris- $\mathrm{HCl}$;

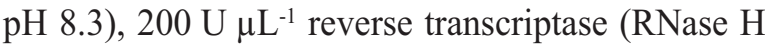
free, Fermentas, Leon-Rot, Germany), $10 \mathrm{mmol} \mathrm{L}^{-1}$ of each dNTP, and $50 \mu \mathrm{mol} \mathrm{L}^{-1}$ of oligo(dT) primer. RT reaction was carried out at $25^{\circ} \mathrm{C}$ for $10 \mathrm{~min}$, followed by $1 \mathrm{~h}$ at $42{ }^{\circ} \mathrm{C}$, and completed with denaturation at $99^{\circ} \mathrm{C}$ for $5 \mathrm{~min}$. Reaction tubes containing RT preparations were then flash-cooled in an ice chamber until used for DNA amplification through polymerase chain reaction (PCR) (37).

\section{RT-PCR assay}

First-strand cDNA was used as a template for semi-quantitative RT-PCR with a pair of specific primers in a $25-\mu$ Lreaction volume. The sequences of specific primer and product sizes are listed in Table 1.
$\beta$-Actin was used to normalise mRNA levels of the target genes. The reaction mixture for RT-PCR consisted of $10 \mathrm{mmol} \mathrm{L}^{-1} \mathrm{dNTP}$ 's, $50 \mathrm{mmol} \mathrm{L}{ }^{-1} \mathrm{MgCl}_{2}$, 10x PCR buffer $\left(50 \mathrm{mmol} \mathrm{L}^{-1} \mathrm{KCl} ; 20 \mathrm{mmol} \mathrm{L}^{-1}\right.$ Tris$\mathrm{HCl} ; \mathrm{pH} 8.3), 1 \mathrm{U}_{\mu} \mathrm{L}^{-1}$ taq polymerase, and autoclaved water. Table 1 lists the specific gene primer sequences and PCR cycling conditions. PCR products derived from $\beta$-actin were then loaded onto $2.0 \%$ agarose gel. Each RT-PCR was repeated for each rat, generating at least ten new cDNA products per group.

\section{Statistical Analysis}

All data were analysed with one-way analysis of variance using SAS general linear models procedure (38) followed by Scheffé's test to assess differences between groups. The values are expressed as mean \pm SEM. The level of significance was set at $P<0.05$.

\section{RESULTS}

\section{Rat survival and body weight}

There were no significant differences in the survival rate between the control and $o$-cresol-exposed

Table 1 Primers and PCR thermocycling parameters

\begin{tabular}{|c|c|c|c|}
\hline Gene & Primer sequence $\left(5^{\prime}-3^{\prime}\right)$ & Conditions of the PCR assay & $\begin{array}{c}\text { PCR } \\
\text { amplicons } \\
\text { (bp) }\end{array}$ \\
\hline \multirow{2}{*}{ CYP3A } & GAA GCA TTG AGG AGG ATC AC & \multirow{2}{*}{$\begin{array}{l}25 \text { cycles: } 94{ }^{\circ} \mathrm{C}, 40 \mathrm{~s} ; 54{ }^{\circ} \mathrm{C}, 40 \mathrm{~s} ; 72^{\circ} \mathrm{C}, 45 \mathrm{~s} \\
\text { Final extension: } 72{ }^{\circ} \mathrm{C}, 5 \mathrm{~min}\end{array}$} & \multirow{2}{*}{376} \\
\hline & GGG TTG TTG AGG GAA TCC AC & & \\
\hline \multirow{2}{*}{$\mathrm{COX} 2$} & CTG TAT CCC GCC CTG CTG GTG & \multirow{2}{*}{$\begin{array}{l}25 \text { cycles: } 94^{\circ} \mathrm{C}, 30 \mathrm{~s} ; 65^{\circ} \mathrm{C}, 30 \mathrm{~s} ; 68^{\circ} \mathrm{C}, 1 \mathrm{~min} \\
\text { Final extension: } 68^{\circ} \mathrm{C}, 2 \mathrm{~min}\end{array}$} & \multirow{2}{*}{279} \\
\hline & ACT TGC GTT GAT GGT GGC TGT CTT & & \\
\hline \multirow{3}{*}{$\operatorname{PPAR} \gamma$} & TGT GTG ACA GGA AAC AGC TAT GAC & \multirow{3}{*}{$\begin{array}{l}30 \text { cycles: } 94^{\circ} \mathrm{C}, 30 \mathrm{~s} ; 65^{\circ} \mathrm{C}, 30 \mathrm{~s} ; 72{ }^{\circ} \mathrm{C}, 1 \mathrm{~min} \\
\text { Final extension: } 72{ }^{\circ} \mathrm{C}, 2 \mathrm{~min}\end{array}$} & \multirow{3}{*}{384} \\
\hline & CAT G & & \\
\hline & $\begin{array}{l}\text { ATG CAG GTT CGT AAA ACG ACG GCC } \\
\text { AGT }\end{array}$ & & \\
\hline \multirow{2}{*}{ BAX } & ACA AAG ATG GTC ACG GTC TGC C & \multirow{2}{*}{$\begin{array}{l}25 \text { cycles: } 94^{\circ} \mathrm{C}, 30 \mathrm{~s} ; 65^{\circ} \mathrm{C}, 30 \mathrm{~s} ; 68^{\circ} \mathrm{C}, 1 \mathrm{~min} \\
\text { Final extension: } 68^{\circ} \mathrm{C}, 2 \mathrm{~min}\end{array}$} & \multirow{2}{*}{429} \\
\hline & GGT TCA TCC AGG ATC GAG ACG g & & \\
\hline \multirow{2}{*}{ BCL2 } & CTC AGT CAT CCA CAG GGC GA & \multirow{2}{*}{$\begin{array}{l}25 \text { cycles: } 94^{\circ} \mathrm{C}, 30 \mathrm{~s} ; 65^{\circ} \mathrm{C}, 30 \mathrm{~s} ; 68^{\circ} \mathrm{C}, 1 \mathrm{~min} \\
\text { Final extension: } 68^{\circ} \mathrm{C}, 2 \mathrm{~min}\end{array}$} & \multirow{2}{*}{450} \\
\hline & AGA GGG GCT ACG AGT GGG AT & & \\
\hline \multirow{2}{*}{ AKT-1 } & TAC CTG AAG CTA CTG GGC AAG & \multirow{2}{*}{$\begin{array}{l}35 \text { cycles: } 93{ }^{\circ} \mathrm{C}, 30 \mathrm{~s} ; 56{ }^{\circ} \mathrm{C}, 45 \mathrm{~s} ; 74{ }^{\circ} \mathrm{C}, 45 \mathrm{~s} \\
\text { Final extension: } 74{ }^{\circ} \mathrm{C}, 10 \mathrm{~min}\end{array}$} & \multirow{2}{*}{270} \\
\hline & GAG AAG AAG GTG GAC AGA GCA & & \\
\hline \multirow{2}{*}{$\mathrm{PKC} \alpha$} & TGA ACC CTC AGT GGA ATG AGT & \multirow{2}{*}{$\begin{array}{l}30 \text { cycles: } 93{ }^{\circ} \mathrm{C}, 30 \mathrm{~s} ; 60{ }^{\circ} \mathrm{C}, 45 \mathrm{~s} ; 74{ }^{\circ} \mathrm{C}, 45 \mathrm{~s} \\
\text { Final extension: } 74^{\circ} \mathrm{C}, 10 \mathrm{~min}\end{array}$} & \multirow{2}{*}{325} \\
\hline & GGC TGC TTC CTG TCT TCT GAA & & \\
\hline \multirow{2}{*}{$\beta$-Actin } & GTG GGC CGC TCT AGG CAC CAA & \multirow{2}{*}{$\begin{array}{l}25 \text { cycles: } 94^{\circ} \mathrm{C}, 30 \mathrm{~s} ; 65^{\circ} \mathrm{C}, 30 \mathrm{~s} ; 68^{\circ} \mathrm{C}, 1 \mathrm{~min} \\
\text { Final extension: } 68^{\circ} \mathrm{C}, 2 \mathrm{~min}\end{array}$} & \multirow{2}{*}{540} \\
\hline & CTC TTT GAT GTC ACG CAC GAT TTC & & \\
\hline
\end{tabular}




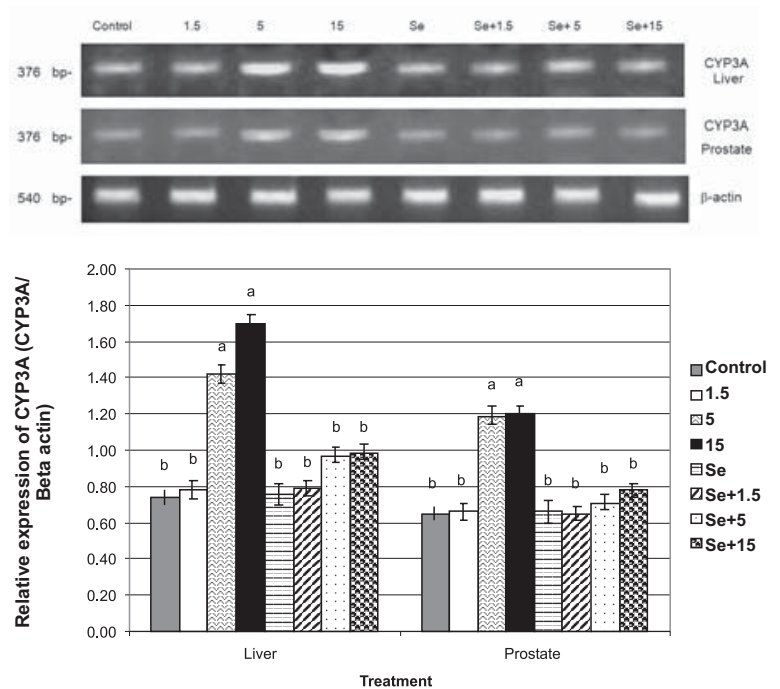

Figure 1 Semi-quantitative RT-PCR confirmation of CYP3A gene in male rats treated with 0 -cresol $\left(1.5 \mathrm{~g} \mathrm{~kg}^{-1}, 5\right.$ $\mathrm{g} \mathrm{kg}^{-1}$, or $15 \mathrm{~g} \mathrm{~kg}^{-1}$ ) with or without selenium $\left(0.1 \mathrm{mg} \mathrm{kg}^{-1}\right)$ for 8 weeks. " $a$ " is significantly different from " $b$ " $(P<0.05)$.
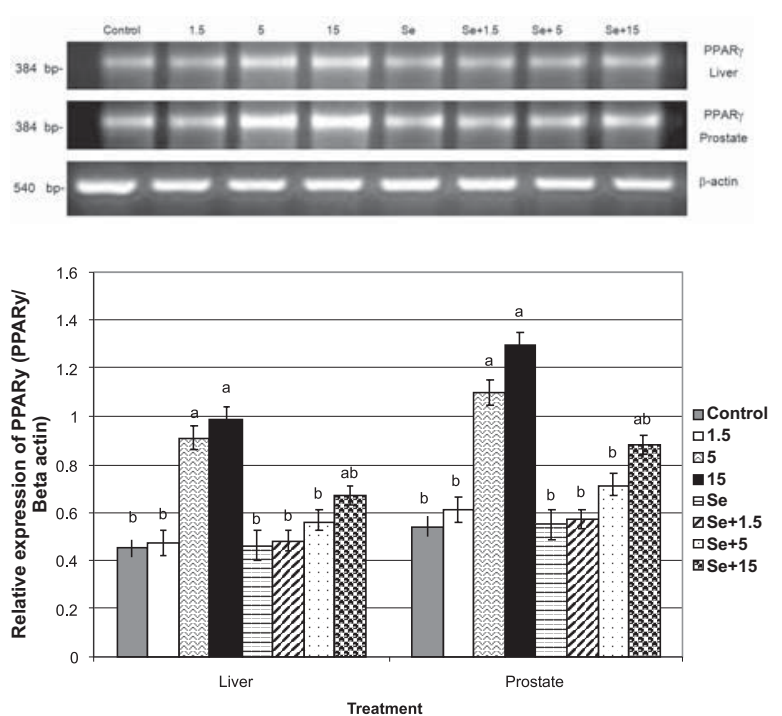

Figure 3 Semi-quantitative RT-PCR confirmation of PPAR gene in male rats treated with o-cresol $\left(1.5 \mathrm{~g} \mathrm{~kg}^{-1}, 5\right.$ $\mathrm{g} \mathrm{kg}^{-1}$, or $15 \mathrm{~g} \mathrm{~kg}^{-1}$ ) with or without selenium $\left(0.1 \mathrm{mg} \mathrm{kg}^{-1}\right)$ for 8 weeks. " $a$ " is significantly different from " $b$ " $(P<0.05)$, but neither " $a$ " or " $b$ " are significantly different from " $a b$ ".

groups. Approximately $91 \%$ of the animals (range $87 \%$ to $97 \%$ ) survived to the end of the study.

Mean body weights of rats receiving $1.5 \mathrm{~g} \mathrm{~kg}^{-1}$ (group 2) and $5 \mathrm{~g} \mathrm{~kg}^{-1} \mathrm{o}$-cresol (group 3) did not significantly differ from control over time. However, mean body weight of rats exposed to $15 \mathrm{~g} \mathrm{~kg}^{-1} O$-cresol (group 4 ) was only $84 \%$ of control by the end of the

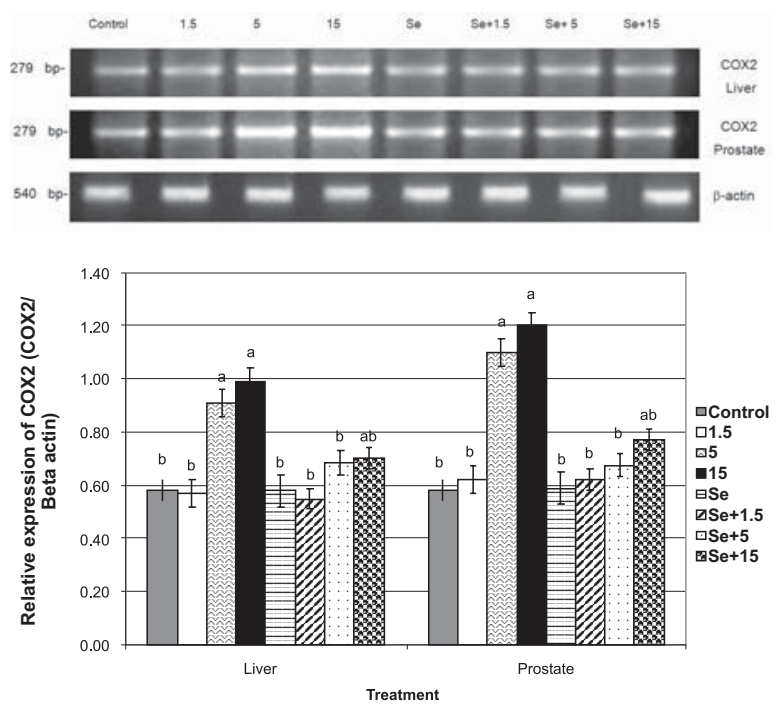

Figure 2 Semi-quantitative RT-PCR confirmation of COX-2 gene in male rats treated with o-cresol $\left(1.5 \mathrm{~g} \mathrm{~kg}^{-1}, 5\right.$ $\mathrm{g} \mathrm{kg}^{-1}$, or $15 \mathrm{~g} \mathrm{~kg}^{-1}$ ) with or without selenium $\left(0.1 \mathrm{mg} \mathrm{kg}^{-1}\right)$ for 8 weeks. " $a$ " is significantly different from " $b$ " $(P<0.05)$, but neither " $a$ " or " $b$ " are significantly different from " $a b$ ".
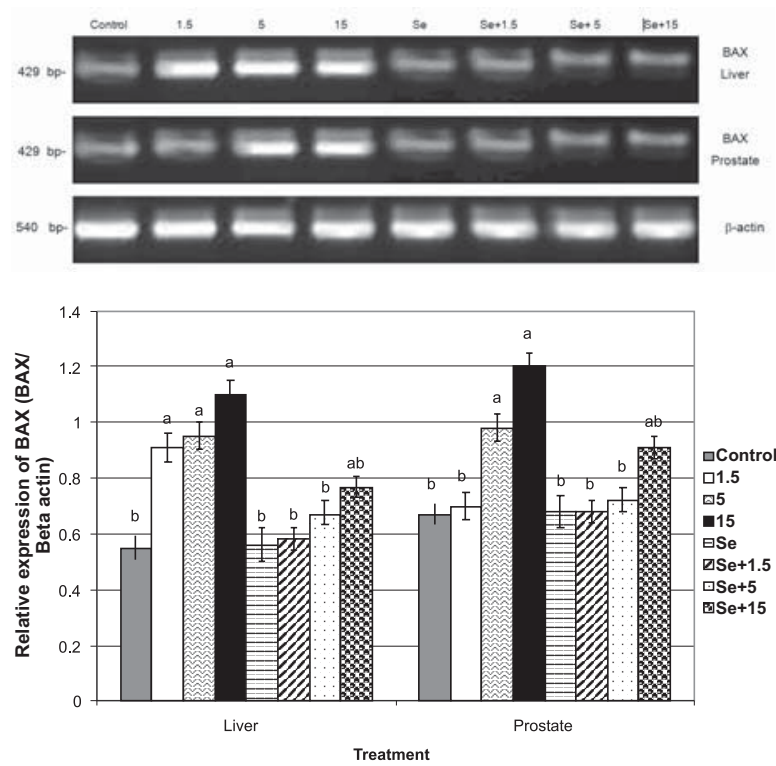

Figure 4 Semi-quantitative RT-PCR confirmation of BAX gene in male rats treated with o-cresol $\left(1.5 \mathrm{~g} \mathrm{~kg}^{-1}, 5 \mathrm{~g}\right.$ $\mathrm{kg}^{-1}$, or $\left.15 \mathrm{~g} \mathrm{~kg}^{-1}\right)$ with or without selenium $(0.1 \mathrm{mg}$ $\mathrm{kg}^{-1}$ ) for 8 weeks. " $a$ " is significantly different from " $b$ " $(P<0.05)$, but neither " $a$ " or " $b$ " are significantly different from " $a b$ ".

study (446 g vs. $498 \mathrm{~g} ; \mathrm{P}<0.05$ ). The difference in mean weight gain was apparent within one week of the study (131 g vs. $142 \mathrm{~g})$. Feed consumption in group 4 was lower than in controls in the first week $(10.4 \mathrm{~g}$ day $^{-1}$ vs. $17.4 \mathrm{~g}$ day $\left.^{-1}\right)$, but recovered to near control levels by the second week (16.1 $\mathrm{g}^{-1 a y^{-1}}$ vs. $17.2 \mathrm{~g}$ day $^{-1}$ ). 

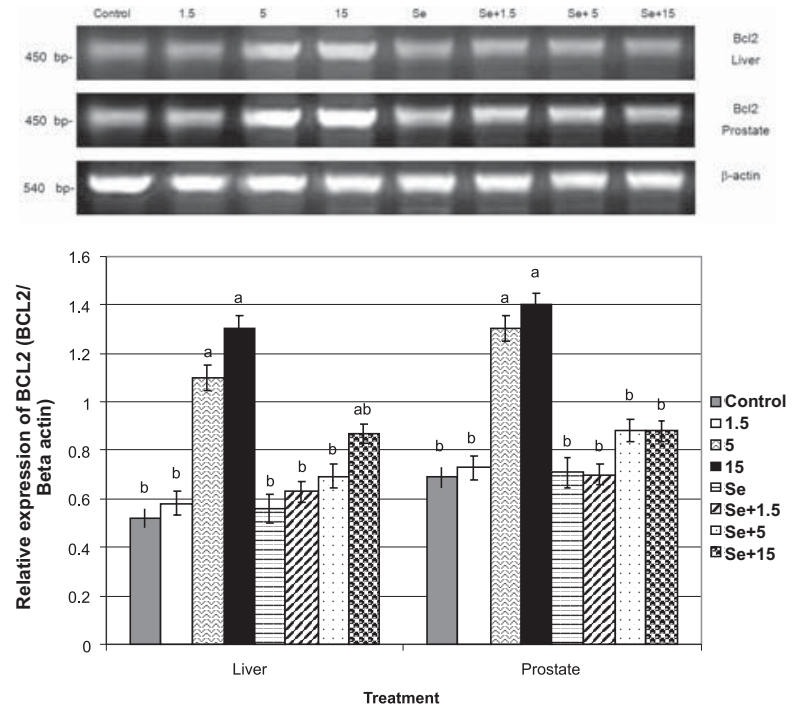

Figure 5 Semi-quantitative RT-PCR confirmation of BCL2 gene in male rats treated with o-cresol $\left(1.5 \mathrm{~g} \mathrm{~kg}^{-1}, 5\right.$ $\mathrm{g} \mathrm{kg}^{-1}$, or $\left.15 \mathrm{~g} \mathrm{~kg}^{-1}\right)$ with or without selenium $(0.1 \mathrm{mg}$ $\left.\mathrm{kg}^{-1}\right)$ for 8 weeks. " $\mathrm{a}$ " is significantly different from " $b$ " $(P<0.05)$, but neither " $a$ " or " $b$ " are significantly different from " $a b$ ".

Gene expression

CYP3A gene was more expressed in the liver than in prostate tissues. In contrast, COX-2, PPAR $\gamma$, BAX, BCL2, AKT-1, and PKC $\alpha$ genes were more expressed in prostate tissues than in the liver.

In groups 3 and 4, liver CYP3A was significantly higher than in control and other treated groups, while exposure to low-dose $o$-cresol (group 2) did not increase CYP3A expression in comparison to the control group (Figure 1). Treatment with Se (group 5) did not increase CYP3A expression in the liver and prostate tissues and it remained similar to control group (Figure 1). Moreover, Se lowered CYP3A overexpression induced by $5 \mathrm{~g} \mathrm{~kg}^{-1}$ (group 7) and $15 \mathrm{~g}$ $\mathrm{kg}^{-1} \mathrm{o}$-cresol (group 8 ) in the liver and prostate tissue (Figure 1).

Groups 3 and 4 also showed increased expression of COX-2, PPAR $\gamma$, BAX, BCL2, AKT-1, and PKC $\alpha$ genes (Figures 2-7), while group 2 remained within the control range, save for BAX, whose expression in the liver was significantly higher than in control (Figure 4).

In group 5 on Se alone, COX-2, PPAR $\gamma, \mathrm{BAX}$, BCL2, AKT-1 and PKC $\alpha$ expression in the liver and prostate tissues was similar to control (Figures 2-7). Se significantly to lowered COX-2, PPAR $\gamma, \mathrm{BAX}$, BCL2, AKT-1, and PKC $\alpha$ over-expression in the liver and prostate tissues of group 7 (Figures 2-7) and significantly lowered BCL2, AKT-1, and PKC $\alpha$ in
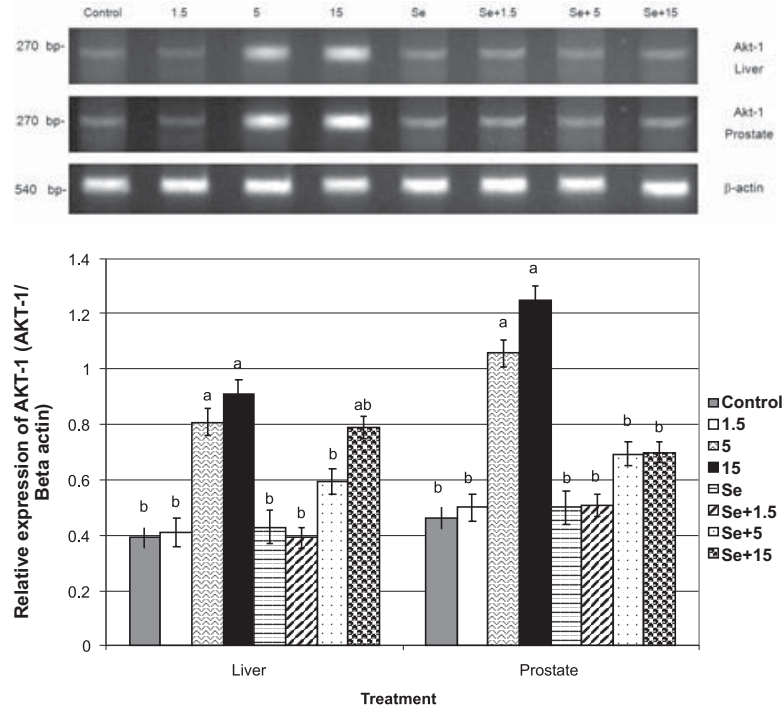

Figure 6 Semi-quantitative RT-PCR confirmation of AKT-1 gene in male rats treated with o-cresol $\left(1.5 \mathrm{~g} \mathrm{~kg}^{-1}, 5\right.$ $\mathrm{g} \mathrm{kg}^{-1}$, or $\left.15 \mathrm{~g} \mathrm{~kg}^{-1}\right)$ with or without selenium $(0.1 \mathrm{mg}$ $\mathrm{kg}^{-1}$ ) for 8 weeks. " $\mathrm{a}$ " is significantly different from " $b$ " ( $P<0.05)$, but neither " $a$ " or " $b$ " are significantly different from " $a b$ ".

prostate tissues of group 8 (Figures 5-7). It also significantly lowered over-expression of $\mathrm{PKC} \alpha$ in the liver of group 8 (Figure 7). However, it could not significantly lower the over-expression of COX-2, PPAR $\gamma$, and BAX in the liver of the most exposed group 8 (Figures 2-4).
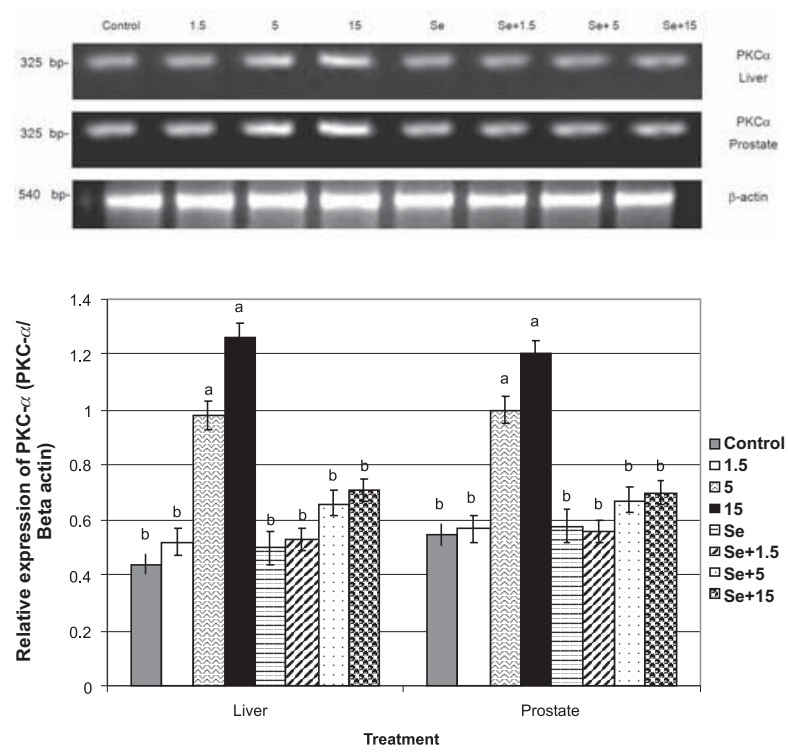

Figure 7 Semi-quantitative RT-PCR confirmation of $P K C a$ gene in male rats treated with o-cresol $\left(1.5 \mathrm{~g} \mathrm{~kg}^{-1}, 5\right.$ $\mathrm{g} \mathrm{kg}^{-1}$, or $\left.15 \mathrm{~g} \mathrm{~kg}^{-1}\right)$ with or without selenium $\left(0.1 \mathrm{mg} \mathrm{kg}^{-1}\right)$ for 8 weeks. " $a$ " is significantly different from " $b$ " $(P<0.05)$ 


\section{DISCUSSION}

This study was conducted to determine the expression of cancer-related apoptotic genes in male rats exposed to o-cresol in order to fill the gap in data on chronic cresol toxicity that may be relevant for human exposure.

While $o$-cresol did not affect survival, animals with the highest exposure $\left(15 \mathrm{~g} \mathrm{~kg}^{-1}\right)$ ate less in the first week, which eventually reflected on their body weight, even though they returned to normal feeding by the second week. This is in agreement with the findings by Sanders et al. (19), whose rats exposed to a $15 \mathrm{~g}$ $\mathrm{kg}^{-1}$ mixture of $m$ - and $p$-cresols had a significantly lower body weight than controls in the first week of exposure. These results were attributed to unpalatability of the feed containing high amounts of cresols.

Cresols are known respiratory irritants in humans and animals (2) and concentrations higher than $15 \mathrm{~g}$ $\mathrm{kg}^{-1}$ would probably have irritated the respiratory and other biological membranes of our rats.

Our study confirmed that $o$-cresol affects the expression of apoptotic genes that are indicators of cancer development. CYP3A was higher in the liver than in prostate tissues, but COX-2, PPAR $\gamma, \mathrm{BAX}$, BCL2, AKT-1, and $\mathrm{PKC} \alpha$ were higher in prostate tissues than in the liver. Similarly, Lehman-McKeeman et al. (39) found that exposure of mice to environmental xylene increased CYP3A mRNA level in the liver. In addition, Badawi et al. (40) reported that overexpression of COX-2, PPAR $\gamma$, BAX, BCL2, AKT-1, and $\mathrm{PKC} \alpha$ genes was responsible for prostate cancer in aged rats.

Only a few studies have investigated the carcinogenic potential of cresols. Boutwell and Bosch (17) and Yanyscheva et al. (18) have suggested that cresols promote tumours in rodents. Villard et al. (41) found that cytochrome P450 isozymes CYP1A, CYP2B, CYP2E, and CYP3A were involved in liver and lung carcinogenesis in mice exposed to cigarette smoke.

Some believe that prostate cancer is associated with altered hormonal milieu $(42,43)$, lowered apoptotic potential (44-46), lowered antioxidant enzyme activity (47), and accumulation of DNA damage (48). Although these changes are all implicated in carcinogenesis, the precise mechanism underlying prostate cancer development remains unclear. According to Badawi et al. (20), one of key players in prostate cancer is cyclooxygenase-2 (COX-2), which can serve as an early predictor of cancer risk.
Selenium, on the other hand, was able to inhibit over-expression of CYP3A, COX-2, PPAR $\gamma$, BAX, BCL2, AKT-1, and $\mathrm{PKC} \alpha$ genes in rats exposed to 5 $\mathrm{g} \mathrm{kg}^{-1}$ and $15 \mathrm{~g} \mathrm{~kg}^{-1} O$-cresol. Selenium is involved in antioxidant defence (25) and is associated with anticancer activity $(28,29)$. Legg et al. (49) reported that high dietary intake of Se reduces prostate cancer risk.

Cellular glutathione peroxidase (GPx) is the first identified selenoprotein and there is a strong correlation between blood Se and GPx activity (50). GPx acts as an antioxidant by directly reducing $\mathrm{H}_{2} \mathrm{O}_{2}$, and lipid hydroperoxides cleaved by phosphor-lipase A2 (50). Therefore, inhibited over-expression of CYP3A, COX2, PPAR $\gamma, \mathrm{BAX}, \mathrm{BCL} 2$, AKT-1, and PKC $\alpha$ in our study may be related to higher activity of GPX and/or other antioxidant enzymes in male rats treated with Se. This remains to be verified or rejected by future studies, which should look deeper into the mechanisms underlying the protective effect of Se.

\section{REFERENCES}

1. World Health Organization (WHO). Cresols. Environmental Health Criteria 168. Geneva: WHO; 1995.

2. Kirk-Othmer. Alkylphenols. In: Kirk-Othmer Encyclopedia of Chemical Technology. $5^{\text {th }}$ ed. Vol. 2. New York (NY): John Wiley \& Sons; 2004. p. 203-33.

3. Kilic M, Lindsay RC. Distribution of conjugates of alkylphenols in milk from different ruminant species. J Dairy Sci 2005;88:7-12.

4. Guillén MD, Errecalde MC, Salméron J, Casas C. Headspace volatile components of smoked swordfish (Xiphias gladius) and cod (Gadus morhua) detected by means of solid phase microextraction and gas chromatography-mass spectrometry. Food Chem 2006;94:151-6.

5. Schwarzbauer J, Littke R, Weigelt V. Identification of specific organic contaminants for estimating the contribution of the Elbe river to the pollution of the German Bight. Org Geochem 2000;31:1713-31.

6. Thornton SF, Quigley S, Spence MJ, Banwart SA, Bottrell $\mathrm{S}$, Lerner DN. Processes controlling the distribution and natural attenuation of dissolved phenolic compounds in a deep sandstone aquifer. J Contam Hydrol 2001;53:233-67.

7. Atagana HI, Haynes RJ, Wallis FM. Optimization of soil physical and chemical conditions for the bioremediation of creosote-contaminated soil. Biodegradation 2003;14:297307.

8. Tortajada-Genaro LA, Campíns-Falcó P, Bosch-Reig F. Unbiased spectrophotometric method for estimating phenol or o-cresol in unknown water samples. Anal Bioanal Chem 2003;376:413-21.

9. Morville S, Scheyer A, Mirabel P, Millet M. Spatial and geographical variations of urban, suburban and rural atmospheric concentrations of phenols and nitrophenols. Environ Sci Pollut Res 2006;13:83-9. 
10. Agency for Toxic Substances and Disease Registry (ATSDR). Toxicological Profile for Cresols 2008 [displayed 4 February 2011]. Available at http://www.atsdr.cdc.gov/toxprofiles/ tp34.pdf.

11. Wafaa MA, Khalil WKB, Eshak MG. Genotoxicity studies on the removal of a direct textile dye by a fungal strain, in vivo, using micronucleus and RAPD-PCR techniques on male rats. J Appl Toxicol 2008;28:484-90.

12. Wu ML, Tsai WJ, Yang CC, Deng JF. Concentrated cresol intoxication. Vet Hum Toxicol 1998;40:341-3.

13. Dills RL, Bellamy GM, Kalman DA. Quantitation of o-, $\mathrm{m}$ - and $\mathrm{p}$-cresol and deuterated analogs in human urine by gas chromatography with electron capture detection. J Chromatogr B Biomed Sci Appl 1997;703:105-13.

14. Pierce CH, Chen Y, Dills RL, Kalman DA, Morgan MS. Toluene metabolites as biological indicators of exposure. Toxicol Lett 2002;129:65-76.

15. Vernot EH, MacEwen JD, Haun CC, Kinkead ER. Acute toxicity and skin corrosion data for some organic and inorganic compounds and aqueous solutions. Toxicol Appl Pharmacol 1977:42:417-23.

16. Monma-Ohtaki J, Maeno Y, Nagao M, Iwasa M, Koyama H, Isobe I, Seko-Nakamura Y, Tsuchimochi T, Matsumoto T An autopsy case of poisoning by massive absorption of cresol a short time before death. Forensic Sci Int 2002;126:77-81.

17. Boutwell RK, Bosch DK. The tumor-promoting action of phenol and related compounds for mouse skin. Cancer Res 1959;19:413-24.

18 Yanysheva NYa, Balenko NV, Chernichenko IA, Babiy VF. Peculiarities of carcinogenesis under simultaneous oral administration of benzo(a)pyrene and o-cresol in mice. Environ Health Perspect 1993;101(Suppl. 3):341-4.

19. Sanders JM, Bucher JR, Peckham JC, Kissling GE, MR Hejtmancik GE, Chhabra RS. Carcinogenesis studies of cresols in rats and mice. Toxicology 2009;257:33-9.

20. Badawi AF. The role of prostaglandin synthesis in prostate cancer. Br J Urol Int 2000;85:451-62.

21. Gupta S, Srivastava M, Ahmad N, Bostwick DG, Mukhtar H. Over-expression of cyclooxygenase-2 in human prostate adenocarcinoma. Prostate 2000;42:73-8.

22. Shiota G, Okubo M, Noumi T, Noguchi N, Oyama K, Takano Y, Yashima K, Kishimoto Y, Kawasaki H. Cyclooxygenase2 expression in hepatocellular carcinoma. Hepatogastroenterology 1999;46:407-12.

23. Shi XB, Gumerlock PH, deVere White RW. Molecular biology of prostate cancer. World J Urol 1996;14:318-28.

24. May WS, Tyler PG, Ito T, Armstrong DK, Qatasha KA, Davidson NE. Interleukin-3 and bryostatin-1 mediate hyperphosphorylation of BCL2a in association with suppression of apoptosis. J Biol Chem 1994;269:26865-70.

25. Rayman MP. The importance of selenium to human health. Lancet 2000;365:233-41.

26. Mihailović MB, Avramović DM, Jovanović IB, Pesut OJ, Matić DP, Stojanov VJ. Blood and plasma selenium levels and GSH-PX activities in patients with arterial hyperten- sion and chronic heart disease. J Environ Pathol Toxicol Oncol 1998;17:285-9.

27. Yoshizawa K, Ascherio A, Morris JS, Stampfer MJ, Giovannucci E, Baskett CK. Prospective study of selenium levels in toenails and risk of coronary heart disease in men. Am J Epidemiol 2003;158:852-60.
28 Rayman MP. Selenium in cancer prevention: a review of the evidence and mechanism of action. Proc Nutr Soc 2005;64:527-42.

29. Kellen E, Zeegers M, Buntinx F. Selenium is inversely associated with bladder cancer risk: a report from the Belgian case-control study on bladder cancer. Int J Urol 2006;13:11804.

30. Khadadah ME, Dashti H. Serum selenium concentration in patients with asthma and its relationship to duration and severity. Trace Elem Electrolytes 2005;22:216-21.

31. Faure P. Protective effects of antioxidant micronutrients (vitamin E, zinc and selenium) in type 2 diabetes mellitus. Clin Chem Lab Med 2003;41:995-8.

32. Brown KM, Arthur JR. Selenium, selenoproteins and human health: a review. Public Health Nutr 2001;49:593-9.

33. Keshan Disease Research Group of the Chinese Academy of Medical Sciences (KDRGCAMS). Observations on effect of sodium selenite in prevention of Keshan disease. Chin Med J 1979;92:471-6.

34. Khalil WKB, Abd El- Kader HAM, Eshak MG, Farag IM, Ghanem KZ. Biological studies on the protective role of artichoke and green pepper against potential toxic effect of thermally oxidized oil in mice. Arab J Biotech 2009;12:2740.

35. NTP Report on the Toxicity Studies of Cresols (CAS Nos. 95- 48-7, 108-39-4, 106-44-5) in F344/N Rats and B6C3F1 Mice (Feed Studies). Toxicity Report Series No. 9. U.S. Department of Health and Human Services, Public Health Service, National Institutes of Health, 1992 [displayed 2 March 2011]. Available at http://ntp.niehs.nih.gov/ntp/htdocs/ ST_rpts/tox009.pdf.

36. El-Makawy AI, Girgis SM, Khalil WK. Developmental and genetic toxicity of stannous chloride in mouse dams and fetuses. Mutat Res 2008;657:105-10.

37. Ali FKh, El-Shafai SA, Samhan FA, Khalil WKB. Effect of water pollution on expression of immune response genes of Solea aegyptiaca in Lake Qarun. Afr J Biotechnol 2008;7:1418-25.

38. SAS Institute. SAS User's Guide: Statistics. Cary (NC): SAS Institute Inc.; 1982.

39. Lehman-McKeeman LD, Johnson DR, Caudill D. Induction and inhibition of mouse cytochrome P-450 2B enzymes by musk xylene. Toxicol Appl Pharmacol 1997;142:169-77.

40. Badawi AF, Liu Y, Eldeen MB, Morrow W, Razak ZR, Maradeo M, Badr MZ. Age-associated changes in the expression pattern of cyclooxygenase- 2 and related apoptotic markers in the cancer susceptible region of rat prostate. Carcinogenesis 2004;25:1681-8.

41. Villard PH, Seree EM, Re JL, De Meo M, Barra Y, Attolini L, Dumenil G, Catalin J, Durand A, Lacarelle B. Effects of tobacco smoke on the gene expression of the Cyp1a, Cyp2b, Cyp2e, and Cyp3a subfamilies in mouse liver and lung: relation to single strand breaks of DNA. Toxicol Appl Pharmacol 1998;148:195-204.

42. Griffiths K. Estrogens and prostatic disease. International Prostate Health Council Study Group. Prostate 2000;45:87100.

43. Banerjee PP, Banerjee S, Brown TR. Increased androgen receptor expression correlates with development of agedependent, lobe specific spontaneous hyperplasia of the 
Brown Norway rat prostate. Endocrinology 2001;142:406675 .

44. Bettuzzi S, Strocchi P, Marinelli M, Astancolle S, Davalli P, Corti A. Gene relaxation and aging: changes in the abundance of rat ventral prostate SGP-2 (clusterin) and ornithine decarboxylase mRNAs. FEBS Lett 1994;348:255-8.

45. Marinelli M, Quaglino D, Bettuzzi S, Strocchi P, Davalli P, Corti A. Increased levels of clusterin mRNA in the ventral prostate of the aging rat are associated to increases in cuboidal (atrophic) cell population and not to changes in apoptotic activity. Biochem Cell Biol 1994;72:515-21.

46. Banerjee S, Banerjee PP, Brown TR. Castration-induced apoptotic cell death in the Brown Norway rat prostate decreases as a function of age. Endocrinology 2000;141:82132 .
47. Ghatak S, Ho SM. Age-related changes in the activities of antioxidant enzymes and lipid peroxidation status in ventral and dorsolateral prostate lobes of noble rats. Biochem Biophys Res Commun 1996;222:362-7.

48. Malins DC, Johnson PM, Wheeler TM, Barker EA, Polissar NL, Vinson MA. Age-related radical-induced DNA damage is linked to prostate cancer. Cancer Res 2001;61:6025-8.

49. Legg RL, Tolman JR, Lovinger CT, Lephart ED, Setchell $\mathrm{KD}$, Christensen MJ. Diets high in selenium and isoflavones decrease androgen-regulated gene expression in healthy rat dorsolateral prostate. Reprod Biol Endocrinol 2008;24:6:57.

50. Rotruck JT, Pope AL, Ganther HE, Swanson AB, Hafeman DG, Hoekstra WG. Selenium: biochemical role as a component of glutathione peroxidase. Science 1973;179:58890. 


\section{Sažetak}

\section{ZAŠTITNO DJELOVANJE SELENIJA PROTIV PREKOMJERNE EKSPRESIJE APOPTOTSKIH GENA POVEZANIH S KARCINOMOM U ŠTAKORA IZLOŽENIH $O$-KREZOLU}

Krezoli su monometilni derivati fenola koji se često rabe kao otapala te kao posrednici u proizvodnji dezinfekcijskih sredstava, mirisa, pesticida, boja i eksploziva. Otuda i njihova rasprostranjenost u okolišu. Opća je populacija izložena krezolima uglavnom putem zraka.

$\mathrm{U}$ ovome se toksikološkom istraživanju ocijenilo djelovanje $o$-krezola, jednoga od tri krezolova izomera, na ekspresiju gena u tkivima jetre i prostate mužjaka štakora. Istraživanje je provedeno na 80 mužjaka, od kojih je 60 tijekom osam tjedana bilo izloženo $o$-krezolu $\left(1,5 \mathrm{~g} \mathrm{~kg}^{-1}, 5 \mathrm{~g} \mathrm{~kg}^{-1}\right.$, odnosno $\left.15 \mathrm{~g} \mathrm{~kg}^{-1}\right) \mathrm{preko}$ krmiva. Tri skupine štakora primale su uz o-krezol nadomjestak selenija u dozi od $0.1 \mathrm{mg} \mathrm{kg}^{-1}$ (Se, u obliku natrijeva selenita) radi ocjene njegove djelotvornosti protiv toksičnosti $o$-krezola. Kontrolna skupina nije primala ni $o$-krezol ni Se, dok je jedna skupina primala samo Se. Preživljenje je bilo podjednako u svih skupina životinja. Štakori izloženi najvišoj dozi o-krezola $\left(15 \mathrm{~g} \mathrm{~kg}^{-1}\right)$ imali su $16 \%$ manju tjelesnu masu od kontrolne skupine na kraju ispitivanja, što može biti povezano s lošim okusom krmiva zbog primjese visoke doze $o$-krezola.

$\mathrm{S}$ istekom osmotjednoga izlaganja o-krezolu životinje su eutanazirane te su prikupljeni uzorci tkiva jetre i prostate. Analiza m-RNA pokazala je značajno povišenu ekspresiju apoptotskih gena CYP3A, COX-2, PPAR $\gamma$, BAX, BCL2, AKT-1 i PKC $\alpha$, koji su povezani s nastankom karcinoma u skupinama štakora izloženim $o$-krezolu $\left(5 \mathrm{~g} \mathrm{~kg}^{-1}\right.$ i $15 \mathrm{~g} \mathrm{~kg}^{-1} \mathrm{u}$ odnosu na kontrolu. Ova je prekomjerna ekspresija poništena u štakora koji su primali selenij. Još nisu jasni mehanizmi iza ovoga zaštitnog djelovanja, na što će odgovoriti buduća istraživanja.

KLJUČNE RIJEČI: apoptotski geni, derivati fenola, RT-PCR, elementi u tragovima

\section{CORRESPONDING AUTHOR:}

Dr Wagdy K. B. Khalil

Cell Biology Department, National Research Center

El Tahrir Street, 12622 Dokki, Giza, Egypt

E-mail:wagdykh@yahoo.com 